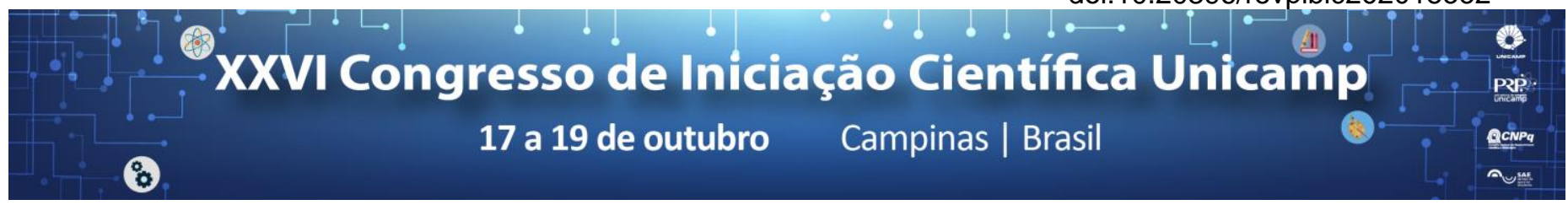

\title{
A Leitura da Morte no Butô de Tatsumi Hijikata
}

\section{Daniel Ribeiro Fernandes Aleixo*, Eduardo Okamoto}

\begin{abstract}
Resumo
A presente pesquisa de cunho descritivo e exploratório - prático-teórica, derivada da minha Iniciação Científica titulada "A Leitura da Morte no Butô de Tatsumi Hijikata" pela FAPESP orientada pelo Prof. Dr. Eduardo Okamoto, trata sobre as origens do Butô, tendo especialmente a morte como tema na obra do ator e bailarino Tatsumi Hijikata, uma das principais referências da criação desta manifestação cênica. $O$ estudo do Butô nos permite uma compreensão da imagem identitária do corpo japonês a partir da década de 1950.
\end{abstract}

\section{Palavras-chave:}

Butoh, Teatro, Japão

\section{Introdução}

O Butô é uma dança performática nascida em 1959. Para se entender a origem do Butô e de seus significados, é necessário entender as memórias do criador, Tatsumi Hijikata. Toda a sua experiência de vida recebeu fortes influências dos rumos assumidos por seu país materno. A sua dança e o seu corpo foram severas críticas a uma situação que afetava não só a ele, mas a todos os demais japoneses, sendo assim uma dança de resistência nacional durante muito tempo. Muito do que se sabe sobre as reflexões de Tatsumi Hijikata se encontra nos registros pessoais do próprio em forma de manifestos, onde o dançarino sempre buscou expor o seu desequilíbrio, os seus desejos mais medonhos e a sua relação com as memórias do passado e as angústias do presente, visto a sua preocupação com o futuro capitalista. Seus escritos são cheios de neologismos, frutos do contato com o surrealismo. A presença da morte é algo bastante presente constante nas suas anotações como na sua própria dança. É imprescindível falar sobre seu Butô sem falar sobre morte, pois essa é uma das bases da própria dança.

\section{Resultados e Discussão}

O corpo ambicionado por Tatsumi Hljikata, chamado de Corpo Morto, consiste no esvaziamento do seu ser social (Shintai) para vir a ser um ser vazio (Karada), um caráter herdado do pensamento zen-budista que dialoga com o $\mathrm{Ma}$ (intervalo entre o espaço e o tempo onde acontecem os rituais e a arte). Esse processo é uma metamorfose onde o indivíduo abandona o seu comportamento, a sua personalidade e os seus trejeitos para criar um corpo receptivo a todos os estímulos. É introduzido o conceito de corpo carne (Nikutai), um corpo totalmente orgânico e cético, sem imaginário ou fantasia, é simplesmente o organismo falando por si mesmo, sem influências intelectuais. Além disso, o sexo e a morte mostram-se como faces complementares na metodologia do criador desta dança transgressora do Japão do século $X X$. Uma linguagem completamente corporal, onde a mensagem é passada por meio de um eterno definhar.

O estudo foi pautado no fichamento bibliográfico dos manifestos do próprio Tatsumi Hijikata e de autores como Jean Genet, Yukio Mishima, Éden Peretta, Marquês de Sade, Christine Greiner, etc, e na análise filmográfica das coreografias de Butô pelos grupos performáticos de Hijikata, disponíveis na internet e em DVDs. O resultado foi duplo, sendo o primeiro uma reflexão detalhada sobre os vários aspectos de leitura que Hijikata fez usando a Morte como seu prisma e o segundo como um trabalho prático dividido em duas apresentações: a encenação solo "Vento Daruma" (2017) e a leitura dramática do manifesto traduzido "Para a prisão" (2018). É importante para o pesquisador de artes mergulhar profundamente na linguagem a que se predispõe, portanto, arriscar uma encenação foi primoroso para que o corpo anatômico também tivesse ciência do que estava sendo pensado como pesquisa. Através das origens do Butô, é possível compreender a imagem identitária do corpo japonês a partir da década de 1950 e sua repercussão nos dias de hoje e em que âmbitos isso atingiu o restante do mundo. No mais, uma dissecação crítica de uma forma artística de revolta em um momento conturbado na história do Japão.

\section{Conclusões}

O fazer artístico japonês na dança Butô possui extrema importância em um contexto acadêmico em que as formas das artes da cena no Japão, quando estudadas no Brasil, prestigiam em sua maioria o seu âmbito tradicional e milenar, como o teatro Nô e o Kabuki. Mesmo os pesquisadores das artes cênicas japonesas da modernidade e contemporaneidade possuem trabalhos escritos muito restritos que representam os únicos materiais disponíveis em português sobre 0 assunto, já que poucos dos manifestos originais de Tatsumi Hijikata e até mesmo os cadernos de cada um dos seus discípulos estão disponíveis em inglês e francês e menos ainda em português, vindo muitas vezes em fragmentos selecionados como citação de pesquisa. O Butô tem conexão direta com o hibridismo cultural pósguerra e é um resultado da antropofagia cultural.

\section{Agradecimentos}

Agradecimentos ao Instituto de Artes da Unicamp pelo espaço de estudo, à FAPESP pelo incentivo, e ao Prof. Dr. Eduardo Okamoto pela orientação.

PERETTA, Éden. O soldado nu. 1 ed. São Paulo: Perspectiva, 2015.

TDR - The Drama Review, Cambridge, v. 44, n. 1, spring 2000.

GREINER, Christine. Leituras da morte. 1 ed. São Paulo: Annablume, 2007. 